\title{
Reform of an Experimental Course of Chemical Engineering Based on Project-Based Teaching Method
}

\author{
Jun Wang*, Zijun Song, Quanliang Li \\ Zhoukou Normal University, Zhoukou, China \\ Email: "zk-wangjun@163.com
}

Received 25 July 2016; accepted 22 August 2016; published 25 August 2016

Copyright (C) 2016 by authors and OALib.

This work is licensed under the Creative Commons Attribution International License (CC BY). http://creativecommons.org/licenses/by/4.0/

(c) (i) Open Access

\begin{abstract}
Project-based teaching method is a practical object-oriented teaching model, which demands to achieve the intended purpose of designed teaching objectives within a stipulated time. Compared to the traditional teaching process, it especially emphasizes a student-centered and self-learning process under teacher's organization. The more important point is that it cultivates college students' sense of engineering application, and expands a new model to cultivate practical and creative ability for students in chemical engineering major. In this paper, this method was utilized in chemical engineering experiment course to realize new teaching model and promote teaching reform.
\end{abstract}

\section{Keywords}

Project-Based Teaching Method, Chemical Engineering Experiment Course, Practical Ability, Evaluation

\section{Subject Areas: Education}

\section{Introduction}

College students in China are now facing with a serious situation, finding a job is becoming much more difficult than ever, while many enterprises are complaining about shortage of practical and technical personnel. Thus the Ministry of Education declares to promote a new round of education reforms in order to encourage the second rank local universities to convert into application-oriented university [1]. Among these engineering majors, the chemical engineering experiment course is a compulsory basic course of the Chemical Engineering major. As we know, traditional talent cultivation mode of normal universities always pay large attention to theory learning,

"Corresponding author.

How to cite this paper: Wang, J., Song, Z.J. and Li, Q.L. (2016) Reform of an Experimental Course of Chemical Engineering Based on Project-Based Teaching Method. Open Access Library Journal, 3: e2921.

http://dx.doi.org/10.4236/oalib.1102921 
ignoring the cultivation of practice ability, which results in the confliction of labor shortage and difficult employment. Thus, a new practical teaching mode in place of traditional one is an urgent need [2]. So, how to organize and implement the teaching reform of this course is a problem of great concern.

Project-based teaching method is a relatively new practical teaching and learning mode, its core education concept originated from John Dewey, an educational theorist of United States, which focuses on a particular discipline and principles designed to bring students into a meaningful task to complete the process, to enable students to actively and independently learn knowledge. It emphasizes that knowledge is not to be taught by teachers but by students themselves with the help of teachers and other students [3], so most universities have realized the importance of student practice in the process of learning. It is aimed at cultivating students' engineering knowledge, individual innovation ability and teamwork spirit to solve specific problems.

Chemical engineering experiment course is a very important experimental course of college students majored in engineering, because almost every engineering majors must learn this course such as chemical engineering, biological engineering, and pharmaceutical engineering.

In this paper, project-based teaching method was adopted to apply into the teaching process of chemical engineering experiment course.

\section{Construction of Project-Based Teaching Method in Chemical Engineering Experiment}

According to the course syllabus, the chemical engineering experiment course includes ten experiments, such as Reynold's experiment, distillation experiment and $\mathrm{CO}_{2}$ absorption experiment and so on. We take flowmeter measurement experiment for an example to interpret how to employ project-based teaching method into teaching [4].

The conventional procedure of project-based teaching method consists of the following aspects (see in Figure 1).

\subsection{Preparation Phase}

This phase mainly examines students' basic chemical engineering theory. Firstly, the task of this project is allocated by teacher. Secondly, every student should clearly understand the goal and the structure of the experimental device in advance especially the usage of Orifice-plate flowmeter, Vnturi flowmeter and Centrifugal pump, review the relevant theory learned in class like the continuity equation of water flow, the calculation formula of flow velocity measured by flowmeter and the measurement of volume flow. At last, each student should master the common operation of ceramic valves, fittings, pressure gage. During this period, student's self-learning and actively learning abilities are developed gradually [5].

\subsection{Plan Phase}

This phase mainly examines students' basic engineering skills including calculation ability, drawing technique and engineering concept [6]. In this phase, students in groups are required to draw the flow chart of the experiment by AutoCAD, make a professional experiment plan and procedures in detail and write preview report respectively. All these work should submit to experimental teachers for check before formally execution.

\subsection{Group Decision Phase}

This phase is designed to mainly observe and examine learning ability, communication ability and teamwork consciousness of students. During this period, four students will be arranged in one group according to the need of this project, one is in charge of operation of pump, another takes care of pressure of the two flowmeter, the last two students are in charge of measurement of flow volume. Each group member puts forward his plan and

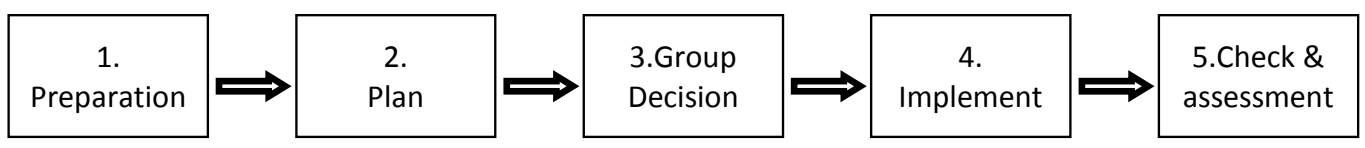

Figure 1. The conventional procedure of project-based teaching method. 
suggestion based on his previous investigation and survey. Then after carefully discuss on the procedures, operations and cautions of the project, a unified plan would come to an agreement. Decide personnel allocation, and be familiar with his responsibility. Students should share out the project and cooperate with each other in groups to fulfill the experiment.

Teacher must join into the group discussion, while his role is not to teach but to guide and inspire students to obtain a reasonable and feasible way to realize the goal of the project. It is important that teacher should prepare some schemes and questions that may happen in the implement process and record every student's performance during the discussion [7].

\subsection{Implement Phase}

After the first three phases' preparation and discussion, group students will carry out the designed plan leaded by the group leader. In the process of implement, students might encounter some unexpected problems, which requires all group members to co-operate and overcome obstacles depended on wisdom of team. Teacher should observe students' operations and performance and give some advice or instruction if necessary so as to assess their grades. In this phase, students are urged to cope with problems flexibly, and their teamwork and cooperation spirit is trained.

\subsection{Check and Assessment Phase}

This phase is a key part of the whole project, which fully demonstrates advantages of project-based teaching method over traditional mode, as it uses a novel evaluation system to examine students' comprehensive performance [8]. The evaluation system consists of three assessment tables, i.e. student's self-evaluation table, group's evaluation table and teacher's evaluation table, scoring in each table respectively accounts for $20 \%, 30 \%$ and $50 \%$ of student's total marks. The universal table template is listed as below (see in Table 1). Through self-evaluation

Table 1. Project-based teaching evaluation.

\begin{tabular}{|c|c|c|c|}
\hline \multicolumn{2}{|l|}{ Project item: } & \multirow{2}{*}{$\begin{array}{l}\text { Name: } \\
\text { Evaluation criterion }\end{array}$} & \multirow{2}{*}{$\begin{array}{l}\text { Group No. } \\
\text { Scoring (point) }\end{array}$} \\
\hline Evaluation item & Evaluation factor & & \\
\hline \multirow{4}{*}{ Operation skills } & \multirow{4}{*}{$\begin{array}{l}\text { Operation standards, } \\
\text { Skill levels }\end{array}$} & Excellent operation & 30 \\
\hline & & Better operation & 25 \\
\hline & & Average operation & 20 \\
\hline & & Bad operation & $0-19$ \\
\hline \multirow{8}{*}{ Professional conduct } & \multirow{2}{*}{ Attendance rate } & $100 \%, 99 \%-85 \%, 84 \%-60 \%$ & $20,15,8$ \\
\hline & & $\leq 59 \%$ & $0-3$ \\
\hline & \multirow{3}{*}{$\begin{array}{l}\text { Experimental notes and operation } \\
\text { records }\end{array}$} & Most complete and tidy & 10 \\
\hline & & More complete and tidy & 8 \\
\hline & & Incomplete and untidy & $2-4$ \\
\hline & \multirow{3}{*}{ Experimental attitude } & Most Serious and responsible & 10 \\
\hline & & More Serious and responsible & $6-8$ \\
\hline & & Common behavior & $0-5$ \\
\hline \multirow{3}{*}{$\begin{array}{l}\text { Quality of project } \\
\text { finished }\end{array}$} & \multirow{3}{*}{$\begin{array}{l}\text { Degree of quality in each phase and } \\
\text { time spent }\end{array}$} & $90 \%$ task dong in specified time & 15 \\
\hline & & $80 \%$ task dong in specified time & 12 \\
\hline & & $60 \%$ task dong in specified time & 5 \\
\hline Self-learning ability & $\begin{array}{l}\text { Master of relevant knowledge and } \\
\text { technology }\end{array}$ & Excellent, good, mean and bad & $5,4,3,0$ \\
\hline $\begin{array}{l}\text { Cooperation and } \\
\text { communication ability }\end{array}$ & $\begin{array}{l}\text { Degree of participation and } \\
\text { organization }\end{array}$ & Excellent, good, mean and bad & $5,4,3,0$ \\
\hline Concluding report & $\begin{array}{l}\text { Objectivity, comprehensiveness and } \\
\text { logic }\end{array}$ & Excellent, good, mean and bad & $5,4,3,0$ \\
\hline Final scoring & & & $\leq 100$ \\
\hline
\end{tabular}


and teacher's assessment, students rethink merits and demerits in the whole process and then promote students' practical ability.

\section{Conclusion}

The project-based teaching method focuses on the dominant role of students in the teaching/learning process, and it helps students understand industrial reality, gain knowledge and skills, and improve their overall ability. Students can participate in the experiment with the greatest interest, which fully arouses the enthusiasm of selflearning and actively innovation so as to deepen the understanding of the theory knowledge. This teaching method helps students improve their ability of putting theoretical knowledge into practice, and contributes to their employment.

\section{Acknowledgements}

This work is supported by the Program for Science \& Technology Research Projects of Henan Province (No. 142300410353).

\section{References}

[1] Zhu, J. and Tu, X.H. (2014) Brief Analysis of Application of Project Teaching Method in Mechanical Undergraduate Teaching Practice. Journal of Shenyang Normal University (Natural Science Edition), 32, 577-580.

[2] Zhou, Y.J., Gao, L.A. and Liu, S. (2013) Cultivating the Innovative Ability of College Students. World Transactions on Engineering and Technology Education, 11, 304-309.

[3] Keenan, B. (1977) The Dewey Experiment in China: Educational Reform and Political Power in the Early Republic. Harvard University Press, Cambridge, MA, 20-30.

[4] Fan, Y.J. (2008) The Research and Practice on Project-Based Teaching Method in Chemical Technology Course. Journal of Changchun University of Science and Technology (Higher Education Edition), 4, 74-76.

[5] Zhang, X.J., Zheng, Y., Wang, J.K., Zhao, G.S. and Du, J. (2014) Teaching Reform and Practice of Chemical Fundamental Experimental in Teaching of Normal University. Journal of Lanzhou University of Arts and Science (Natural Science Edition), 28, 117-119.

[6] Wang, D.G. (2014) Application of Project Teaching Method in Single Chip Microcomputer. Experiment Science and Technology, 12, 105-107.

[7] Lin, J.H. (2013) Application of Project Teaching Method in General Technology Teaching. Journal of Nanchang College of Education, 28, 125-128.

[8] Helle, L., Tynjäla, P. and Olkinuora, E. (2006) Project-Based Learning in Post-Secondary Education-Theory, Practice and Rubber Sling Shots. Higher Education, 51, 287-314. http://dx.doi.org/10.1007/s10734-004-6386-5

Submit or recommend next manuscript to OALib Journal and we will provide best service for you:

- Publication frequency: Monthly

- 9 subject areas of science, technology and medicine

- Fair and rigorous peer-review system

- Fast publication process

- Article promotion in various social networking sites (LinkedIn, Facebook, Twitter, etc.)

- Maximum dissemination of your research work

Submit Your Paper Online: Click Here to Submit

Contact Us: service@oalib.com 